From the volumes that remain in the Forbes Collection that were written by Englishmen prior to 1610, then, we can discerm little pattern, with the one proviso that there appears to be a slightly disproportionate amount of puritan sermon literature. It remains to be seen whether any more rational and satisfying connection can be established between the man and that part of his library published closer to his actual lifetime.

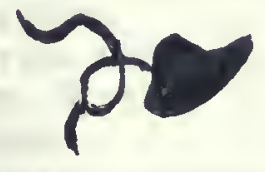

16th CENTURY CONTINENTAL EDITIONS AND AUTHORS IN THE FORBES COLLECTION

by

Natalie Zemon Davis

After 1534, says H.S.Bennett of the English book trade, "foreign competition [was] wellnigh impossible. The English printer had things all his own way." How can this be true when the great publisher Christophe Plantin was sending European editions to fifteen booksellers in London and to several more in Scotland in the 1560's and 1570's? How can this be true when scholarly English libraries of the late 16 th and early 17 th centuries include so many continental editions? - About 70\% of the 750 books in the theological collection of Anthony Higgin (d. 1624), graduate of St. John's College, Cambridge and Dean of Ripon, had been printed accross the Channel - to give only one example.*

This movement of books from Europe to England in the 16th and 17 th centuries has never been fully studied and is difficult to analyse, depending as it does on so many independent variables of market, legal prohibition, printing and transport costs, religion, travel and literary taste. A look at the European editions printed before 1610 in the Forbes Collection suggests both the possibilities and problems of a broad study; it also helps us to see what a non-Conformist minister of the late 17 th and early 18th centuries "remembered" of the religious and intellectual life of continental Europe in the l6th century。

Of the 1500 books in Forbes' library, only about 125 were printed before 1611 , 86 of them on the continent. Once we move into the 17 th century, the ratio changes; the great bulk of Forbes" books were printed in England. Here are some tables to introduce us to the subjects and languages of books printed on the continent before 1611 as well as their date and place of publication.

* H.S.Bennett, English Beoks and Readers, 1475 to 1557 (Cambridge, 1952), p.193. Colin Clair, Christopher Plantin (London, 1960), pp。208-10。 The Library Catalogue of Anthony Higgin, Dean of Ripon (1608-1624), ed。J.E.Mortimer, Proceedings of the Leeds Philosophical and Literary Society, Literary and Historical Section, $\mathrm{X}(1962)$ 
DISTRTBUTION OF SUBJECTS OF 86 PRE-1611 CONTINENTAL EDITIONS

\section{Religious Works}

Bibles with commentaries

Biblical commentaries \& homilies 31

Biblical commonplaces 1

Catechisms

Doctrine and anti-Catholic polemic 17

Church History

Fathers

Scholastic commentaries

Catholic polemic

Sermonwriting

Total religious works

\section{2}

4

2

2

2

68

\section{Secular Works}

Classical authors

10

Non-classical moral and Other

1

LANGUAGE OF PRE-1611 CONTINENTAL EDITIONS

\begin{tabular}{lr} 
Latin & 81 \\
Greek or Latin-Greek & 3 \\
English & 2 \\
\hline Total & 86
\end{tabular}

DATE OF PUBLICATION OF PRE-1611 CONTINENTAL EDITIONS

$\begin{array}{lllr}\text { Before } 1500 & 1 & 1561-1570 & 7 \\ 1500-1510 & 1 & 1571-1580 & 15 \\ 1511-1520 & 0 & 1581-1590 & 10 \\ 1521-1530 & 3 & 1591-1600 & 15 \\ 1531-1540 & 4 & 1600-1610 & 21 \\ 1541-1550 & 2 & \text { no date } & 2 \\ 1551-1560 & 5 & \text { Total } & 86\end{array}$

PLACE OF PUBLICATION OF PRE-1611 CONTINENTAL FDITIONS

\begin{tabular}{|c|c|c|c|c|c|c|}
\hline Switzerland & Germany & & France & & \multicolumn{2}{|c|}{ Low Countries } \\
\hline Basel & Frankfort & 8 & Paris & 4 & Antwerp & 3 \\
\hline Zurich & Cologne & 5 & Lyons & 4 & Dutch cities & 4 \\
\hline Geneva & Wittenberg & 3 & Total & 8 & Total & 7 \\
\hline Other 2 & Other & 8 & & & & \\
\hline Total 46 & Total & 24 & Withor & place & .1 & \\
\hline
\end{tabular}

Now it could be that the Reverend Forbes owned many additional works by 16 th century continental authors, but that they were in editions published after 1610 or in editions printed in England. I have located, however, only 37 such books in Forbes' library, and they do not substantially change the picture already given: 
16th CENTURY CONTINENTAL WORKS PUBLISHED IN. ENGLAND

$\begin{array}{crlr}\text { Published before } & 1611 & \text { Subjects } & \\ \text { In Latin } & 3 & \text { Religious } & 11 \\ \text { In English } & 4 & \text { Secular } & 7\end{array}$

Published after 1611

In Latin 6

In English 5

Total published in

England

18

16th CENTURY CONTINENTAL WORKS PUBLISHED ON THE CONTINENT

AFTER 1610

\begin{tabular}{lrlll} 
Religious works in Latin & 17 & & Published in & \\
Secular works in Latin & 2 & & Germany & 8 \\
\hline Total works published on the & & & Switzerland & 8 \\
Low Countries & 3
\end{tabular}

continent after 1610

19

Thus, the character of Forbes" collection of 16 th century continental editions and authors begins to emerge: Latin religious works, most of them originating in the last half of the 16 th century and published in the Protestant centres of Switzerland and Germany。 This selection is interesting, because it differs in important ways from that which would have been made by Protestant divines living in the later 16th or early 17th centuries. In their libraries the greatest names of continental religious reform were represented by many volumes, but they have only irregular representation among Forbes' books. There is one and only one work by Luther - a commentary on Paul's Epistle to the Galatians (Hagenau, 1535); one Biblical commentary by Brenz; one from Oecolampadius; and nothing from Melancthon, Bullinger or Zwingli。 Bucer's De regno Christi is there (Basel, 1557) as are Beza's Tractationes Theologicae (2nd ed。g Geneva, 1576)。 But Calvin is the only major reformer for whom Forbes had more than one edition - a catechism and three other works. Even then, he owned more volumes by the Zurich pastors Ludwig Lavater and Rudolf Walther (Gwaltherus, d.1586) than by Calvin。

Secondly, libraries built up by Protestant clerics of the late l6th and early 17th centuries were richly supplied with the texts that humanist scholarship had made available to religious reform: numerous texts and fresh translations of Scripture and critical editions of the early fathers. Forbes, in contrast, had only Konrad Pellican's edition of the whole Bible (Zurich, 1532); that of François du Jon and Immanuel Tremellius (Hanover, 1603; interleaved for commentary, though none has been written); and "pre-humanist" editions in Gothic, with commentary by the medieval Nicolas de Lyra (Basel, 1507; Strasbourg, 1492)。 No Erasmus, no Lefève d'Etaples, none of the great Estienne editions。 Similarly, his continental editions of the fathers were limited to Jerome's Epistles, in an edition by the Jesuit Canisius (Paris, 1602) rather than that of Erasmus; Salvian's De Gubernatione. Dei (Geneva, 1600); and two Biblical commentaries by Theophylactus.

The truth is, of course, that the theological problems that exercised Forbes were those of his own time (see Michael Finlayson's article elsewhere in this bulletin and in later issues)。 Nor did Forbes need to concern himself about establishing a correct biblical text。 The l6th century continental works in the collection point to one activity - the study of the Bible and Biblical commentaries, presumably for the purpose of his orm sermons. 
The small number of secular works by l6th century continental authors in Forbes? library reveal little of the literary or scientific movements of the period. There is only one history book that could have told Forbes what happened in Europe in those years: a part of Jacques Auguste De Thou's Latin History of his Om Time (Paris, 1608; this volume included the story of the Saint Bartholomew's Day Massacre)。 Erasmus is the only major humanist to be included: the Adagia (Antwerp, 1533) and the Colloquia (Leyden: Elzevir, 1643). There are a few Ramist works, such as Johann Heinrich Asltedt's Systema Mnemonicum Duplex (Frankfort, 1610), a work that seems to have taught little to the reader, who had to write a list of things - to-remember on the fly-leaf - "pay the Taylor。o Hire the Coach, Visit my Cousin..."

Unable to read any of the continental vernaculars, Forbes was cut off from European poetry, stories, and theatre. Du Bartas is his only poet, in an English translation of the Divine weekes and workes (London, 1608)。 His most interesting scientific work is Theatrum Humanae Vitae (Basel, 1586) by Theodore Zwinger, the reforming dean of the Medical Faculty at Basel. Agrippa of Nettesheim's Vanity of the Sciences also appears among Forbes' books in an English translation (London, 1676); according to Charles Nauert, this extraordinary physician and occultist was frequently mentioned in 17 th century England. On the other hand, it is a surprise to find in a nonconformist's library the Courtier of Castiglione, here in a Latin translation made by Bartholomew Clerke of Cambridge in 1571 (Forbes' edition is London, 1612)。 Perhaps it was used by his pupils。

The most coherent group of books among Forbes' secular editions printed on the continent are the classical texts. Presumably he used these too for his teaching. Some of them are much marked, such as Cicero's Orationes (Lyons: Jean Frellon, 1560; edition not in Baudrier) and a Greek Isocrates (Basel: Thomas Guérin, 1565)。

Where Forbes purchased these books or how much he paid for them he doesn't say. Only in his earliest edition - the Latin New Testament, with commentary by Nicolas de Lyra (Strasbourg. . 1492) - does he write that it was a "gift of ToBrom." It is very probable, however, that most if not all, of the sixteenth century editions had reached England long before Forbes acquired them. Twenty seven of the editions published before 1611 had autographs written in them before Forbes wrote his own name and device. Only two of these omers are definitely Europeans: a Dom Vettor of the Society of Jesus, who wrote his name in Bellarmine's De controversis Christianae fidei (Paris, 1602) and Rodolphe Walther, who owned two of his own books of homilies and probably a copy of Livy. All or almost all the other owners are English or Scottish (their names are listed at the end of this note, in case any of them are of interest to readers). Others of the books have no autographs besides Forbes' oim, but do have English marginalia and English phrases written on the fly-leafs. In only two cases have l6th century owners noted when they acquired the books: William Lewis, who bought the Adagia of Erasmus in 1533, the same year it was published in Antwerp; and "Whittiker", who obtained De Gloria by the Portuguese bishop Jeronimo Osorio in 1589, some thirteen years after it was published in Cologne. It seems likely, however, from the character of the handwriting that a number of the other editions came into English possession during the 16th century。

Why any particular reader obtained any particular book in the Forbes Collection is, of course, not at all evident, except for the school texts. Some of the continental editions had, however, original connections with England which made more likely their arrival on her shores. Beza's Tractationes Theologicae were dedicated from Geneva, 1570, to Walter Mildmay, Queen Elizabeth's Chancellor of the Exchequer; Rudolf Walther dedicated his Homiliae on John's Epistle to Edward VI not long before the young king's death and his Homilies on Paul's Epistle to the Corinthians to 
Edmund Gryndal, Archbishop of York and the Bishops of London, Winchester, Ely, Norwich and Durham. The Protestant Erasmus Sarcerius dedicated the second edition of his Latin Method of Teaching Holy Scripture (Marburg, 1544) to Henry VIII, because, he explained, he had learmed that the first edition had been translated into English at Henry's request.*

Five of the authors whose works were published in continental cities were themselves English: John Knox' Answer to a great Number of blasphemous cavillations written by an Anabaptist was printed in 1560 in Geneva during his exile in Calvin's city; Thomas Harding's Confutation of Jewel's Apology of the Church of England was published in Antwerp in 1565, for the Catholic Harding had been living in Louvain since Elizabeth's accession (see Sinclair, below, item 7), Thomas Brightman's Apocalypsis apocalypseos, dedicated to the holy reformed churches of Britain, Germany and France, may have been published on the continent (Frankfort, 1609) because it could not find an English printer: claiming to be under direct divine inspiration, Brightman described the Church of Fngland as the Laodiciean Church and the churches of Scotland and Geneva as those loved by the Angel of God.

Finally, two of the English authors had continental publishers primarily for business reasons - John Rainolds, the President of Corpus Christi College, Oxford, and Robert Rollock, minister of Edinburgh. Rollock's Latin commentary on the Gospel of John had first editions in Edinburgh and Geneva the same year (1599) and subsequent Geneva editions, including the 1608 edition in the Forbes Collection. Rainolds' De Romanae Ecclesiae Idolatria appeared in 1596 in Oxford and then in 1598 in Geneva. The publisher of the Geneva editions in the Forbes Collection was Jacques Stoer, a German who printed in Geneva for almost fifty years. There may be more trade connections between Genevan publishing houses and Britain than has been previously realized.

The primary importance of the Forbes Collection does not lie in its 16 th century continental editions and authors, yet the data reviewed here suggests it may yield some fresh insights into intellectual and economic connections between England and the continent。

Appendix: SIGNATURES IN 16th CENTURY CONTINENTAL EDITIONS IN THE FORBES COLLECTION

All legible signatures in editions published before 1611 have been included other than Forbes',plus signatures from two interesting editions in 1612。 Prices have been included even when undated, in case they may be of use to some readers. Author, short title and place and date of publication are given, followed by the signatures.

Alstedt, J.H., Systema Mnemonicum (Frankfort, 1610); pr。6s。anno dom。1628 Aretius, B., Commentariis in.opistolas D。 Pauli (Geneva, 1596): D。Parker l£ 12s. Binding papers: English Bible:

Bible. Tertius Liber Moysis.oenaratione Davidis Chytraei, (Wittenberg, 1575):

* On this edition, see further J.M.McConica, English Humanists and Reformation Politics (Oxford, 1965), p. 180 and Sinclair, below, item ?. 
Brenz, J., In Evangelii。o secundum Lucam (Frankfort, 1541-42): William Voiles booke (see Westhemerus below); Jhon domtines $\left(398^{\mathrm{r}}\right)$.

Brightman, To, Apocalypsis (Frankfort, 1609): Perkgede.

Bugenhagen, Jo, In Epistolam Pauli ad Ephesios (Basel, 1524): Richard Barnes $\left(129^{r}\right)$; Booke $\mathrm{S}^{\mathrm{r}}$ Bitnes $\left(128^{\mathrm{V}}\right)$.

Calvin, Jo, Tractatus theologici (Geneva, 1612): Jo: Ball pretium 10s。

Chemnitz, $\mathbb{1}_{\circ}$, Loci Theologii (Frankfort, 1594, 3 vols。): Nat. Bernard pretium hujus et reliquorum 2 volum. $8 \mathrm{~s}$ 6d.

Comes, No, Mythologiae (Geneva, 1612): W.Marshall.

Erasmus, Adagia (Antwerp, 1533): Guillielmi Leuisii, 1533, 18d (See Sinclair below, item 2)。

Gerardus, A., De theologo (Basel, 1572): Veni, vide, vince [sic] Anthonius Dabsonus.

Gorus, J. de Sancto Geminiano, Summa de Exemplis et Rerum similitudinibus (Lyons, 1585): Thomas Leonard pretium 6s 6d。

Hippocrates, Aphorismi Graecè et Latine (Leyden, 1601): Duncandus Brunetus Scotus.

Isocrates, Orationes (in Greek, Basel, 1565): Stephanus Vinallus, Thomas Danson, John Aikenoyd.

Justinus, Historia (title page missing): Richard Cramar.

Knox, Jo, An Answer to...cavillations...by an Anabaptist (Geneva, 1560): Samuell Bames his ow book; Thomas Geater his booke 1642; also several plays of a game resembling tic-tac-toe.

La Ramée, $P_{0}$ de。, De religione Christiana (Frankfurt, 1583): Thomas; "to Simons the haberdasher send the。.o"; "God above \& heaven above \& wrath above relent; And man beneath \& earth beneath \& sin beneath repent."

Lavater, L。, In libros....Chronicorum (Zurich, 1573): Jo. Chapman.

Livy; Historiarum (Basel, 1554): $\mathrm{RG}$ (see Walther, $\mathrm{R}_{0}$ ); mss. in spine binding from reign of Philip and Mary.

Lubbertus, So, De principiis Christianorum Dogmatum (Franeker, 1591): 3s $4 \mathrm{~d}$. Osorio, J。, De Gloria (Cologne, 1576): Wittiker, 1589

Pappus, Jo, In omnes Prophetas (Frankfort, 1593): Mroboyle his booke。

Plutarch, Moralia (Basel, 1572): Anton。 Parker。

Polanus, Aog Symphonia Catholica (Basel, 1607): binding papers are business letters from John Bill, bookseller of London in the late 16 th and early $17^{t h} \mathrm{cog}$ to Mr. John Crosley, Bookseller in Oxford. .

Ravisius, Jos Epistolae (Lyons, 160?): Richard Snay his booke; Joyce his book (p. 11); Gulielmus Pulley eius liber 1640 (p. 154); Richard Wharfe doth not orm this Booke but Josuah 1625 (at back)。

Robert Bellarmine, De controversis Christianae fidei (Paris, 1602): Dom。Vettor Soc。Jesuit。(crossed out)。

Sacchi, B。, De vitis ac gestisooopontificorum (Cologne, 1540): Guliel, Bocherus possessor 6s 8d; Christophorus Windle possesor emit e Jo Knight et aliis et solvit 20s。

Salvian, De gubernatione Dei (Geneva, 1600)。 ToMoozota or Moorota。

Sarcerius, E。, Methodus Scripturae Divinae (Marburg, 1544): James Allen, W。 Masters

(See Sinclair below, item 4)。

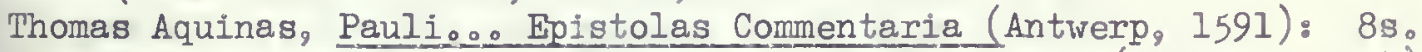

Toletus, Fo, Commentaria.ooinoooAristotelis De Anima (Cologne, 1594): iiis, 4a;

a signature crossed out, perhaps because this work by the Jesuit Tolet was owned by Jesuit house (see Robert Bellarmine above)。

Walther, R。 In Prophetas Duodecimi。Homiliae (Zurich, 1582): RG (G for Gwalther). -... In Acta apostolorum (Zurich, 1562): Rod。Gralth。

Westhemerus, B., Conciliationem.oosacrosanctae scripturae (Zurich, 1552): Unto almightie Godoosum Guli Voile (see Brenz above)。 , In omnes Psalmos Davidis (Basel, 1566): Geo Sley pr。viii. 